size of a case of well-formed internal hemorrhoids. This proved fortunate, for by its simple ligation, a strictured condition resulted which was of great service at the anal orifice. It can be quite understood that the sphincter muscles were so distended by this great mass as to be nearly unrecognizable and without power of control.

The question naturally suggested was whether the muscle would ever regain its power and. if so, to what extent? Also, would this wonderfully thickened gut ever be thinned to assume or approximate the normal. I am glad to report that both conditions were eventually brought about. About one year after the operation was done I examined him, in company with Dr. Geo. J. Cook of Indianapolis, and found good contractile power in the sphincter, and the gut thinned to nearly a normal condition. On June 25 , about two months after the operation, the patient wrote: "I have been using the water-closet, and there is no indication of the bowel coming down." He has continued to improve ever since and gained much in flesh. This case has never been reported.

I conclude: 1 . That in all cases of prolapse of the rectum of the second or third degree, colopexia is to be preferred to all other procedures. 2. That it is the least dangerous of any surgical procedure advised for prolapse. 3. That the uninterrupted suture should be used in preference to the interrupted, especially in cases when the mass is large or the walls of the gut much thickened.

Mr Carlyon, ${ }^{3}$ of London, says that he has only been able to find three cases of colopexia operations. $\mathrm{He}$ does not intimate for what degree of prolapse these were done. The operation referred to by me was done in April, 1899, and at that time I had never heard of its being done. Though, therefore, not original with me, I thought at the time that it was. No case that I have yet heard of compares in magnitude to this one, and I trust that by now reporting it, two years after the operation, the said report may prove of some benefit to those desiring to operate for so formidable a malady. In 1889, Jaennel fixed the colon to an artificial anus wound in the iliac region. Bryant found records of twenty-nine cases done by this method. In my opinion this procedure is not only unnecessary, but unjustifiable. Dr. Bovée, of Washington, reports an interesting case of colopexia done on a woman during an abdominal section after the ovaries and appendages had been removed.

In reporting this case I desire to thank my friend. Dr. Ap Morgan Vance for valuable assistance and suggestions.

\section{SANITARY CONDITIONS OF PEKING.}

JOHN INGIIS, A.M., M.D.

MEMBER OF THE AMERICAN MEDICAL ASSOCIATION. PEKING, CHINA.

The Chinese army has been driven from Peking, the Empress and her co-conspirators have fled, the order is cut for the punishment of the most guilty and the sacred city, we are told, is well patrolled by the foreign soldiers. All true, but those who have lived in Peking know that within a year, unless certain measures are taken, officers and men will discover a deadlier foe than the Empress Dowager's imperial troops, and the death-roll will be longer than it was after the taking of Fort Taku and Tien-Tsin.

Population.-The population of Peking is unknown, perhaps not being so great now as before the recent uprising, but still close to the one million mark. Some writers have greatly overestimated the number of inhabitants in this famous old city. Peking lies near the fortieth degree north latitude,

3. The Irancet. December 1899 . ninety miles from the sea and one hundred and twenty feet above sea-level. It is surrounded to the north and west with mountainous hills, to the south lies the great piain of central China; the latter is sandy but well watered.

Climate.-The climate is similar to that of New York, but much more trying, especially during the spring and summer. From November until March the weather is cold, but March is windy there as elsewhere, and sand storms blow over the city; these are not only disagreeable, but dangerous. In April the temperature rises and in May reaches 90 to $95 \mathrm{de}$ grees F. During May and June thunderstorms and rains are to be expected, and these are frequently the forerunners of an almost continual downpour which lasts from July to the

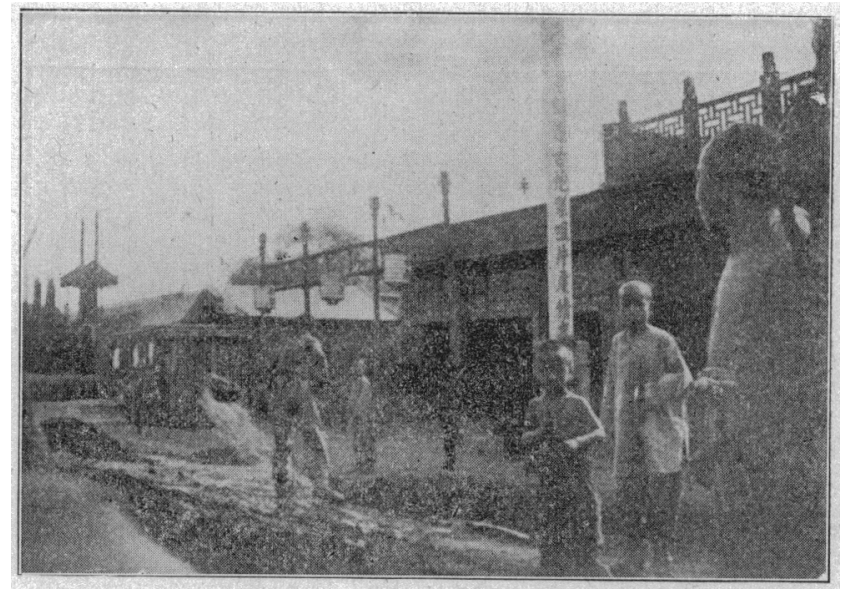

Street Sprinkler

early part of September. The annual rainfall ${ }^{1}$ varies from 46 to 76 inches, but after the rainy season is over, with the exception of some very dusty days, the fall weather is delightful.

Water Supply.-A study of the sanitary conditions of Peking reveals much of a threatening nature and, if it teaches nothing new, throws indisputable proof in favor of cur present ideas concerning the causation of disease. The eity is without water-works, and has no sewerage system worthy of the name. The Chinaman believes in open sewers, claiming that it is better to leave the foul gases free than to pen them beneath the ground. But whether this is based on some scien.

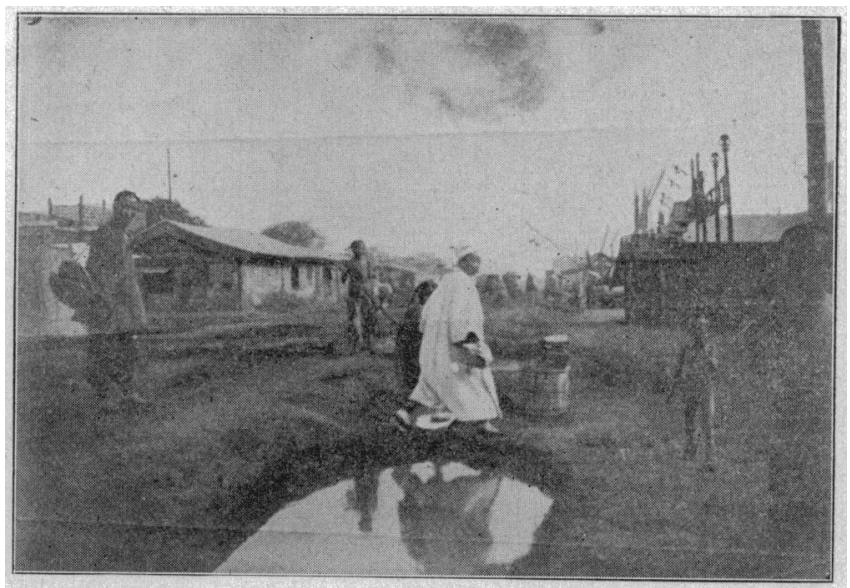

A Cesspool on one of the Main Streets.

tific theory not yet explained, or ignorance of refuse disposal, I can not say, but am inclined to attribute it to ignorance. The water-supply is from wells dug along the sides of the streets; a heavy stone covers the well's mouth and the water is drawn in wooden buckets by rope and pulley; the presence of an open sewer ten feet away, or even running by the mouth of the well, in no way seems to militate against the site on which to sink a well. How often these wells are cleaned out it is impossible to learn, but it may be safely affirmed that they are cleaned only when enough dirt gathers in the bottom to interfere with the filling of the well. The water itself is

1. There is no oflcial record. This is the average for a number of years past. taken by different observers. 
clear and of two varieties, known as "sweet" and "bitter" water. The latter is due to an excess of alkali containing 22 per cent. of hardness, as shown by examination. 'The use of this water means a great deal of kidney trouble. In one year, in a Peking hospital, I have seen more Bright's disease and stone in the bladder than in almost three years spent in connection with much larger hospitals in the United States. Fortunately the Chinese have learned by experience that "raw" water is not good for them, and consequently drink it boiled and colored with a very weak tea:

Street Sprinkling.-The strcet, or traftic way, which is simply an unpaved mud road, is the common receptacle for rub bish, offal and excrement. It is sprinkled-when sprinkled at all-by hand. For this purpose no water can be too filthy. In fact, the cesspool by the roadside is the commun source of sprinkling water.

House Sanitation.-Here we find no alleys as in American cities; each residence is surrounded by a wall, and one compound may contain numerous houses. All the refuse of bedchamber and kitchen finds its disposal upon the street or into an open sewer, where it decays immediately velow the surface of the ground. It must be said, however, that the Chinese kitchen has practically no waste compared with the $\Lambda$ merican. A potato paring is too valuable an article of food to be lightly thrown away.

Every day the manure gatherer may be seen, with a large keg suspended from his shoulders, trudging along the street gathering up the deposit. Here is to be found one of the most disgusting and unsanitary systems in the world; this excre ment from man as well as beast is carried to different quar. ters of the city and prepared for agricultural purposes. From

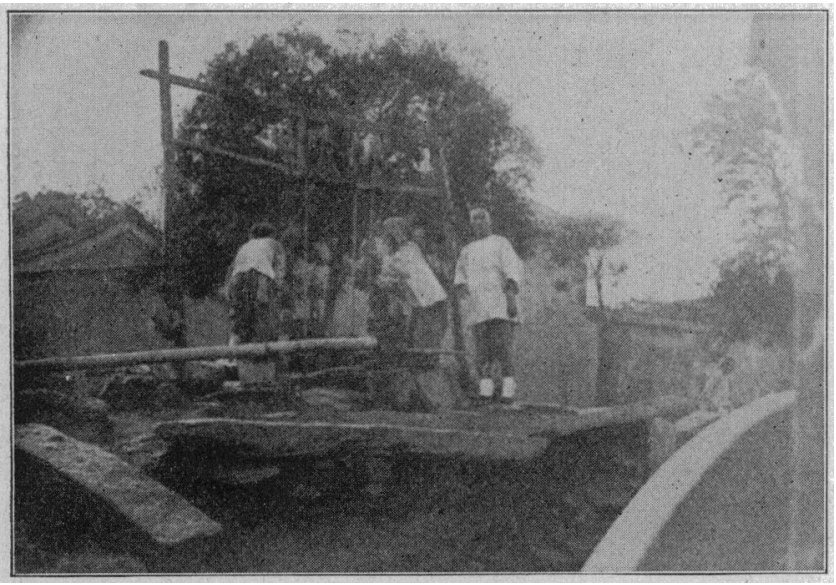

A Street Well.

the sanitarian's point of view this does not need to be dwelt upon; such places are the charnal houses of disease, seething cauldrons disseminating poisonous vapors to be wafted over the city.

Abbattoirs.-In front of meat shops the animals are killed upon the earth thresholds. In fact, on almost any walk along the street the whole process of the abbattoir may be seen.

Former Sanitary Efforts.- Here we have an open violation of the tripod of modern sanitary science, sewerage, watersupply and the disposal of refuse. At one time in the history of the city an effort was made to build large sewers, and the masonry of those they built is creditable; but the system was not general, and that which they did build has fallen into decay, there being little or no effort to keep it in repair. Here and there these old sewers serve a good purpose, but for the most part the refuse and waste water stand reeking in them and in the cess-pools until the stagnant matter is again thrown upon the street by the street sprinkler, to again disseminate its poison into the air.

Peking's Scavengers.-Peking is pre-eminently a city of dogs-large, savage-looking mongrels, but of cowardly spirit. These animals, while the vilest creatures ever seen, eat any thing short of mortar and brick, and contribute greatly to the disposal of refuse; while their presence is a menace to public health, they are of positive usefulness in a city such as the Chinese capital. With these must be mentioned the black hogs of China, which run the city streets unmolested; they are the city scavengers, but add a great element of danger to the health of such a densely populated district.

The Houses.-The dwelling-houses are devoid of anything like a cellar, the floor being laid upon the ground and made of porous brick. Among the poorer classes, the floor is the ground itself. These permit of no circulating medium beneath their apartments, and the gases arising from the earth find ready access to the dwellings. Second story residences are unknown, except those built by foreigners. The windows of the Chinese house are made of lattice-work covered with thin sheets of paper. The rooms are heated, when heated at all, by very small earthenware stoves, in which they burn coal balls made from anthracite coal dust and mud. The rooms are often filled to a dangerous degree with coal gas; thousands of the Chinese die every year from asphyxiation, and it is in these houses with these accommodations that our troops have spent the long cold winter months in China.

Peking's Beggars.-Apart from all sanitary measures as a means of health preservation, nothing can take the place of bodily cleanliness. Beggars, ill-clad and filthy beyond description, cluster around the city gates and sit on every corner. A few years ago, a Chinese official states, in one night four hundred of them froze to death. This number has been greatly exaggerated, but the best Chinese authorities place it at the above figure. These beggars sleep in gateways, or wherever they find it convenient. Whatever may be said of them from the philanthropic point of view, where their number is legion, they are uisseminators of disease, and must be placed among the evils to be removed in placing the city on a sanitary basis.

Disposal of Dead.-In the disposition of the dead Peking has reached the limit of human abominations. If the deceased be wealthy the corpse is kept in the courtyard for weeks. When the day comes for interment the only bearers who can be found to carry the coffin are the beggars, and the wealthier the family the more beggars they add to the procession. The most gruesome sight in connection with this subject is the method in vogue among the poor of disposing of their dead children. Too poverty stricken to provide a Auneral, and holding the superstition that a child who dies before the age of 10 must have been inhabited by a demon, the parents or guardians wrap the body in a coarse straw mat and throw it into the street during the night. At daybreak the dead-cart, drawn by an ox, passes along and the driver gathers up these little cast-out infants and children. It not infrequently hap. pens that an unwanted new-born baby still living is found, and it is taken with the rest and all are buried in a heap outside the eity. The disease of which the child dies is a matter of no consequence, the manner of burial being the same. The ox cart is sometimes assisted by barrow men. A wheel-barrow with double baskets full of little dead smallpox patients was seen one day two years ago down near Legation street. The baskets were full to overflowing, with no covering over the dead, on whose disfigured faces the hot sun was shining.

Means of Conveyance.-The common mode of conveyance in Peking is a mule cart large enough for one passenger to get into and sit upon a padded cotton seat or a fur rug on the cart floor. In them is often to be seen an individual broken out with the smallpox, and the next occupant may have something little better. Cart stands are numerous, and it is safe to say that no carter ever refuses a passenger because of any known disease. No sanitary view of this capital would be complete if it did not consider the influence of these conveyances on the public health.

The itinerant barber is another prolific spreader of diseases peculiar to his trade. The terrific dust storms no doubt carry with them much infection from point to point. A physician who has practiced here for many years has said that the inhabitants of Peking who survive live only by the incessant warfare that goes on between the bacteria themselves, and the ever-faithful phagocyte endeavoring to save us from the disease germs. But here the former is waging a war against terrible odds.

An Object-lesson.-An American bishop who visited Peking recently stated that, on entering the city, he distinguished seventy-two distinct odors. Peking is an appalling objectlesson to those who think too much money is expended in the support of our American boards of health. Any physician who reads this paper can tell, given such conditions, what will be the diseases prevalent. They are such as are to be expected from these surroundings. Cholera is a frequent visitor, cholerine lives there, smallpox is not epidemic but resident, diphtheria is a dreaded foe, typhoid and typhus fevers with malignant malaria and dysentery are always present, and consumption slays its victims by thousands every year. There is also a multitude of skin diseases. In short, every germ-pro. duced disease, and the non-microbic as well, capable of flourishing in this latitude, find their home in this Chinese metropolis. The infant mortality is enormous. 
If the powers intend to hold Peking for any length of time it would be wise to add to that misty antiquity and ancient culture which the present Chinese minister, Mr. Wu Ting Fang, dwells upon so persistently, a chapter on sanitation and approximate cleanliness of people and city; at the same time insure to a greater degree the health of our troops stationed there in the interest of a better eivilization.

One of the conditions that ought to be required of China before admitting her to the society of enlightened nations is that she shall make her capital less dangerous as a place of residence by ridding it of the insanitary conditions that give rise to the enormous prevalence of those diseases that are the product of filth - a remnant of unenlightened ages. Sanitary science applied to Peking would make it as healthy a city as New York or Chicago.

\section{THYROID TISSUE IN THE LARYNX AND TRACHEA.*}

OTTO T. FREER, M.D.

Instructor in Laryngology and Diseases of the Chest, Rush Medical College; Professor of Laryngo-Rhinology, Chicago Policlinic. CHICAGO.

Up to the present time nine cases of thyroid tissue growing within the larynx and trachea have been reported. The histories of these have been collected by Baurowicz, who reports one of his own together with these, in Fränkel's Archives of Laryngology and Rhinology, volume viii, 1898. I have been unable to find a description of the affection since the publication of Baurowicz's article, so think that I can claim that the case of my own that I shall describe is the tenth recorded of this rare affection. Up to the present time the cases reported are 3 by Paul Bruns, 2 by Heise from Bruns' clinic, and 1 each by Ziemssen, Paltauf, Baurowicz and Roth. The principal symptom caused by thyroid tissue in the larynx and trachea is dyspnea. This may have lasted for years, months or weeks before the patient is seen, and generally there is a history of rapidly increasing difficulty of breathing for the last weeks before aid is sought. In a large proportion of the patients tracheotomy is needed to save life. The voice generally does not become hoarse or lose its clearness, as the growth does not ordinarily extend above the lower larynx high enough to interfere with the vibrations and mobility of the vocal cords. An exception to this was in the case of Baurowicz, where one cord was found immobile. Enlargement of the thyroid gland is not a necessary accompaniment of the disorder, but a goiter is quite often present. The thyroid tissue in the larynx and trachea does not cause catarrhal symptoms or irritation, and the dyspnea alone makes us aware of its presence. Where the narrowing of the lumen of the larynx or trachea is sufficient, stenotic breathing becomes noticeable. The ages of the patients vary between 15 and 30 years. The thyroid tissue forms a swelling of variable extent, at times a single tumor being found the size of a pea or bean, other cases presenting diffuse outgrowths occupying a great part of the lower larynx and extending into the trachea.

The most constant situation of the neoplastic swelling is the interior of the cricoid ring. From here the growth is found prolonged into the trachea to a variable distance, the extreme so far found being the fourth tracheal ring. The mucous membrane over the outgrowth is normal in appearance and usually smooth, but in some parts it may present an irregular surface. The tumor has a broad base which merges insensibly into its surroundings. No case is recorded where it was pedunculated. In some cases the thyroid tissue takes the

* Read before the Chicago Isaryngological and Climatolngical Associatien, Nov. 15 . 1900. form of a diffused swelling rather than of a definite tumor. 'This was notably the condition in my own case. As an exceptional site, the location of the growth in the trachea only, without involvement of the larynx, may be mentioned. In all but two cases the tumor was seated on the posterior and lateral wall of the lower larynx and trachea. In one it occupied the anterior wall of the trachea just under the thyroid isthmus. The new-formed tissue is nearly always extensive enough to cause serious dyspnea, great enough at times to necessitate immediate tracheotomy.

The laryngoscopic appearances of the growth usually show a smooth prominence below the vocal cords, over which they move freely and to which they do not seem to be attached. The swelling occupies the hypoglottic space on one or both sides or posteriorly, and in some instances may be seen extending down the trachea in a shadowy way, as the growth in the larynx permits but little light to pass below it. The swelling has a normal color and shows no evidence of inflammatory conditions.

\section{ENTRANCE OF THYROID TISSUE INTO LARYNX AND} TRACHEA.

How does the thyroid tissue enter the larynx and trachea? Up to the time of the report of Paltauf's case the accepted theory was that this thyroid tissue was due to aberration of the embryonic rudiments of the thyroid gland producing an accessory thyroid gland in the larynx, such as is rather often found at the base of the tongue. The postmortem examination of Paltauf's patient, however, showed that this theory was untenable. The moderately enlarged thyroid gland in his case was found firmly grown onto the cricoid cartilage and the first three tracheal rings so that dissection was needed to separate it. This differed from the normal conditions where the larynx and trachea are separated from the thyroid gland by a layer of areolar tissue. Microscopic examination showed that the deeper connective tissue of the submucosa, and the inner perichondrium clear to the cartilage, were infiltrated with the follicles of the thyroid gland. The space between the cricoid and first ring of the trachea, with a piece of the attached thyroid gland, showed direct connection between the inner and outer tumor. The thyroid tissue could be seen to grow into the external perichondrium of the trachea and through the interstitial spaces between the tracheal rings and in this way reach and intimately join the tumor in the larynx and trachea The peripheral layer of follicles of the thyroid gland shows the most energetic proliferation normally, especially at puberty, and if the normal layer of fascia separating the thyroid gland from the larynx and trachea has been omitted in the development of the individual, the thyroid follicles are liable to invade the interstitial spaces between the cartilaginous rings and, by their infiltration, enter the lumen of the larynx and trachea. An actual perforation of the walls of these air-passages is not necessary and has so far not been found. This mode of direct invasion of the tracheal and laryngeal lumen is the one advanced by Paltauf and Baurowicz, and as it has also been accepted by Paul Bruns it seems the correct explanation of the morbid process. Bruns' latest case, in fact, was a strong confirmation of this view, as the thyroid isthmus was found firmly attached to the anterior wall of the trachea directly over the site of the tumor removed by laryngotracheotomv.

Prognosis.-The prognosis of the affection is good if the growth is removed by operation. as the new tissue shows no tendency to reform afterward and as the 